\title{
Beleidsbepaling en aansprakelijkheid
}

\author{
Citation for published version (APA):
}

van Nuland, J. E. (2020). Beleidsbepaling en aansprakelijkheid: Een drieluik over de feitelijke beheersing van vennootschappen. [, Maastricht University]. Maastricht University. https://doi.org/10.26481/dis.20200921jn

Document status and date:

Published: 01/01/2020

DOI:

10.26481/dis.20200921jn

Document Version:

Publisher's PDF, also known as Version of record

\section{Please check the document version of this publication:}

- A submitted manuscript is the version of the article upon submission and before peer-review. There can be important differences between the submitted version and the official published version of record.

People interested in the research are advised to contact the author for the final version of the publication, or visit the DOI to the publisher's website.

- The final author version and the galley proof are versions of the publication after peer review.

- The final published version features the final layout of the paper including the volume, issue and page numbers.

Link to publication

\footnotetext{
General rights rights.

- You may freely distribute the URL identifying the publication in the public portal. please follow below link for the End User Agreement:

www.umlib.nl/taverne-license

Take down policy

If you believe that this document breaches copyright please contact us at:

repository@maastrichtuniversity.nl

providing details and we will investigate your claim.
}

Copyright and moral rights for the publications made accessible in the public portal are retained by the authors and/or other copyright owners and it is a condition of accessing publications that users recognise and abide by the legal requirements associated with these

- Users may download and print one copy of any publication from the public portal for the purpose of private study or research.

- You may not further distribute the material or use it for any profit-making activity or commercial gain

If the publication is distributed under the terms of Article $25 \mathrm{fa}$ of the Dutch Copyright Act, indicated by the "Taverne" license above, 
Control and liability: a triptych on the liabilities of de facto policymakers of companies

This thesis focuses on the de facto control of Dutch companies. After a general introduction (chapter 1) and an explanation of the organisation of companies (chapter 2), the author first discusses the role of management board members of private limited companies and the degree of their autonomy (chapter 3). Next, three types of liability related to the de facto control of companies are discussed. The first is the position of actual (co-) policymakers. In the first part of this chapter the author discusses special statutory provisions in which (co-)policymakers are equated, in terms of liability, with formal directors under the articles. The second part of this chapter includes a study of the liability of (co-)policymakers based on general liability law (chapter 4). The following chapter is also divided into two parts and deals with the Dutch doctrines of piercing the corporate veil. The author first advocates the doctrine of identification in this regard, after which the author discusses the so-called indirect form of piercing the corporate veil from the perspective of groups of companies (chapter 5). The last part of the triptych deals with the liability of limited partners (commanditaire vennoten) under Dutch law. To this end, the author first discusses the current position of limited partners and then discusses proposals to amend the current statutory rules (chapter 6). His conclusion (chapter 7) includes both a contemplation of the triptych and a representation of parallels and contradictions discovered between the three forms of liability for the actual control of companies.

\subsection{Introduction}

The starting point of this research is the autonomy of companies as participants in the legal system on the one hand, and the protection from liability for the persons controlling and owning companies on the other. Under Dutch law, directors of legal entities are in principle protected against liability because their actions are attributed to the company, while the liability of shareholders is by statutory law limited to their contribution. In the case of a limited partnership, the limited partner enjoys the same limitation of liability, but its managing partners have less protection against liability than the directors of legal persons. They are jointly and severally liable. The limitation of liability is justified by a separation of powers and stimulates the entrepreneurial climate. The nexus between policy-making and liability is reflected in different regimes in which, in order to prevent abuse of legal persons, acting as a director is threatened with liability. This forms the common denominator of the three parts of the triptych discussed in this thesis: liability of the (co-)policymaker, identification and liability in group relationships and the liability of limited partners resulting from 
violation of the prohibition for this partner to be involved in the management of the company.

\subsection{Legal personality and liability}

For most legal entities, the aforementioned separation of powers is put in place by a formal distinction between onwnership and control. This distinction is related to the fact that a legal entity is unable to act by itself. Actually participating in a legal system requires the help of people. Company law makes sure that legal persons can participate in legal transactions through natural persons by assigning tasks, responsibilities and powers to the various bodies. The separation of ownership and control can be traced back to companies with a multitude of shareholders, where efficiency demanded that management be outsourced to a separate body. For that reason, the management of the company as well as its participation in the legal system have been assigned to the board of directors. In order to maintain control of their investment, the shareholders jointly have the power to directly or indirectly influence the company's policy, whereas the board of directors is tasked with protecting the interests of all those involved with the company. In this way shareholders retain a say in the company and the board of directors is required to ensure a balanced representation of the interests of both shareholders and other persons involved, such as employees and creditors.

In the absence of this dichotomy, the effective representation of interests may be jeopardised. This is undesirable, since the limitation of liability encourages risk-taking and, therefore, the interests of others than the shareholder are in need of protection. The justification for the limitation of liability is blurred in the absence of the aforementioned dichotomy. An autonomous board of directors is, in principle, capable of ensuring that not only the interests of shareholders are served, but also the interests of others involved in the company. The two-tier structure provides for a balanced distribution of powers in order to ensure that the plurality of interests can be represented in a proportionate manner and requires the natural persons acting on behalf of the company to use their powers in a responsible manner.

However, this does not automatically encourage directors to protect the interests of others involved with the company. The legal personality granted to companies offers directors protection against liability. Director's liability aims to create further protection of interests by sanctioning mismanagement with an obligation to pay compensation for incurred damages. When assessing the liability of directors, shareholders or limited partners, it is always relevant to what extent there has been control over the damaging action, or at least the possibility of preventing the particular action that led to the damage. This indicates an awareness of the personal responsibility of 
natural persons who participate in legal transactions under the protection of legal personality or limited liability. Statutory rules on liability in relation to the de facto management of companies are intended to express this responsibility by providing de facto management with a normative and compensating framework.

\subsection{Management}

This chapter discusses the role and powers of the management board, the possibilities for the management board to represent the company and the degree of autonomy of the management board.

\subsubsection{Role and powers}

Pursuant to section 2:239 paragraph 1 of the Dutch Civil Code (DCC), the management board of a private limited company (besloten vennootschap) is tasked with managing the company. However, statutory law does not provide for an elaborate description of management as such. It is therefore hard to define the scope of this task. The primary function of directors is that of being a manager. In summary, this includes the day-to-day management of the company and its business, as well as determining its strategy and policy for both the short and long term, taking into account the company's objects stated in the articles of association. In addition to preparing, adopting and implementing this policy, the management board also manages the company's assets and acts as an initiator for other bodies of the company. The role and duties of directors depend on, among other things, the nature and size of the business, the objectives of the company and the further allocation of duties and powers within the company's own organisational rules. Each director is required to perform his or her duties properly and to act in accordance with the interests of the company and its business. Under Dutch law, this interest extends beyond the interests of the shareholders and includes the interests of employees and creditors, among others. In addition, directors are tasked with controlling distributions to shareholders. Finally, as manager of the company and its assets, a director must also render the necessary account for, and provide information to, other stakeholders, such as shareholders and, in the event of the company's bankruptcy, the trustee in bankruptcy. The role of directors is not only formed by statutory law, but also by the articles of association of the company and resolutions of the company's bodies. The powers of directors may be extended or limited, but the directors must always retain a certain degree of autonomy. 


\subsubsection{Representation}

The company's participation in legal transactions results in particular from the performance of legal acts by its directors on behalf of the company. Directors derive their power to represent the company from statutory law (for directors of private limited companies enshrined in section 2:240 DCC). The authority to represent the company is always unrestricted and unconditional and may also be granted to persons other than directors. However, the authority of individual directors can be limited. Internal and organisational rules of the company cannot affect this authority. If the company is duly represented, the legal act on its behalf is attributed to the company. The statutory rules on the representation of companies are, again, based on the principle of protection of third parties.

In addition to this statutory power of representation, the company may also be duly represented pursuant to statutory rules on the granting of a power of attorney. Not only directors, but also others can represent the company on the basis of a power of attorney. The scope of a power of attorney may be limited and is also subject to the powers imposed on the principal. A power of attorney may be embedded in a certain legal relationship, an appointment or position and may arise from the appearance of authority to represent the company. Finally, statutory law provides for liability of the person who claims to act by virtue of a power of attorney. In the absence of an adequate power of attorney, the other party can hold that person liable.

\subsubsection{Autonomy of the board of directors}

In the last part of this third chapter, the author considers the autonomy of the board of directors by discussing the authority of other bodies of the company to issue binding or non-binding instructions to the directors of the company. Since 2012, the articles of association of a private limited company may provide that the board is obliged to follow instructions from the corporate body or bodies referred to in such a provision, unless complying with this instruction would be contrary to the interests of the company and its business (section 2:239 paragraph 4 DCC). This authorisation to issue instructions must be distinguished from the de facto power of instruction arising from the power to suspend and dismiss directors of the company. In the legal doctrine, the statutory power of instruction has developed from the perspective of group companies. From this perspective the requirement of central management of a group already implies that the autonomy of directors of subordinated companies is limited. However, over the years a more nuanced view was adopted in case law in which judges considered the balancing of interests, including the interests of subsidiaries in relation to the interest of the group as a whole. At present, the power of instruction in a private limited company is designed in such a way that each instruction is assessed in relation to the company's and its business' interests. 
As a result, the board is required to check each instruction to these interests and, depending on the outcome of such a check, may refuse to comply with an instruction. The author argues that another body of the company cannot give binding instructions to directors. The scope of the power of instruction is then discussed. In addition to a list of the bodies to which this authority can be granted, the author notes the general limitations of the authority to issue instructions. For example, in the articles of association of the company, the power of instruction may be limited by referring to specific subjects, while the company's interests may also indirectly lead to a limitation of the power of instruction. Finally, the standards for assessing both instructions and refusals to comply are discussed. At the end of this chapter, the author argues that judges must substantively exameninstructions to directors and their refusal to comply.

\subsection{Liability of de facto (co-)policymakers}

In the fourth chapter, the author assesses the liability of (co-)policymakers. In doing so, the author distinguishes between liability arising from special statutory provisions that provide for the assimilation of (co-)policymakers with directors on the one hand ('actual policymakers') and liability based on the doctrine of tort, which does not provide for the aforementioned assimilation, on the other hand (false(co-)policymakers').

\subsubsection{Actual (co-)policymakers}

In order to define the (co-)policymaking figure, the author first discusses the parliamentary history of the provisions that provide for the assimilation of (co-)policymakers with directors. To tackle the abuse of legal entities, the (co-)policymaker was introduced into statutory law in the 1980s. The legislator's main objective was to prevent directors of legal entities from escaping liability by allowing straw men to act as directors in their place. Since liability for mismanagement was linked to this formal capacity, it was necessary to provide for provisions that effectively equated (co-)policymakers with directors. It is important to note that the legislator never intended a broad scope for the liability of (co-)policymakers. Moreover, only the (co-)policymaker who actually acted as if he or she were a director may be held liable. This requirement makes it clear that the liability for (co-)policymaking is limited to cases in which corporate powers (f.e. shareholders or supervisory board members) or contractual powers (f.e. employees or advisors) are exceeded. In principle, all responsibility rests with the directors, but the person who, by exceeding his or her authority, comanages the company along with the directors or even sets the directors aside, may be liable in the same way as a director of the company.

In order to qualify the (co-)policymaker, it is important to consider the anti-abuse background that played a role in the introduction of this figure. In 
particular, one should think of cases which reveal an intention to avoid liability for prejudice to creditors by hiding behind the legal personality of a company. In order for a person not formally appointed as a director to be assimilated as such, it is necessary that he or she determined or codetermined the company's policy, whereas in doing so he or she acted as if he or she were a director. For this qualification it is sufficient that this person co-managed the company. Finally, in principle, there must always be an active involvement of the (co-)policymaker in the damaging act.

Pursuant to sections 36 of the Collection of State Taxes Act 1990 (CSTA) and 23 Sectoral Pension Fund (Obligatory Membership) Act 2000 (SPF), directors of entities (a broader context than just legal persons) are jointly and severally liable for certain tax debts and pension premiums respectively, if they do not timely notify the tax authority or pension provider that these debts cannot be paid (notification of inability to pay). They may also be liable if the notification obligation has been met but the debts remain unpaid and it is plausible that the non-payment of these debts is the result of mismanagement attributable to the directors. An explanation of the law on this subject is followed by three caveats in relation to the (co-)policymaker. Firstly, a failure to correctly or timely notify the authority of the inability to pay leads in principle to liability. The author argues that this presumption that leads to liability, without actually determining whether it is a case of mismanagement, should not apply if it appears from the circumstances that the (co-)policymaker was not able to comply with the notification obligation because he or she was not authorised to do so. Secondly, the collective nature of these provisions means that directors cannot disculpate by referring to the (co-)policymaker, since the directors always have their own responsibility. However, the mere circumstance that (co-)policymaking has taken place cannot solely lead to liability. Thirdly, the possibilities for equation in section 36 CSTA and section 23 SPF respectively influence each other. Consequently, in applying these provisions, a legal entity-(co-)policymaker ${ }^{1718}$ and its possible (co-)policymakers may also be held liable. The corporate law equivalent which provides for the liability of legal entity-directors (section 2:11 DCC) lacks such an effect. The referral in that provision is limited to the formal directors of legal entity-directors.

Pursuant to section 2:248 DCC each director is jointly and severally liable for the deficit in a bankruptcy of the company in case of mismanagement and when it is plausible that this mismanagement is a major cause of the bankruptcy. Policymakers share this fate. After a general explanation of these rules, the author once again makes several caveats in relation to the (co-)policymaker. First of all, the circumstance that on the basis of section 2:248 DCC, second paragraph, in the event of a violation of the obligation

${ }^{1718}$ Under Dutch law directors can either be natural persons or legal entities. 
to keep records (section 2:10 DCC) or a violation of the obligation to publish the annual accounts (section 2:394 DCC), liability is in principle established. This principle also applies with respect to (co-)policymakers, although they do not necessarily have the powers required for the proper performance of their duties, including the power to involve themselves in the administration of the company or the annual accounts. The author argues that the Supreme Court has wrongly assumed responsibility for (co-)policymakers with respect to the duty of administration and the duty to publish. Secondly, it is doubtful whether the (co-)policymaker can effectively invoke the disculpatory powers of this provision. After all, the involvement of the (co-)policymaker in the mismanagement is often decisive in determining whether he or she can be regarded as a (co-)policymaker. Moreover, the (co-)policymaker may lack the ability to meet the requirements for an appeal to disculpation, since he is not formally authorised to oppose mismanagement of the directors or to take measures to avert the consequences thereof. In addition, the (co-)policymaker does not always realise that he or she qualifies as such and should therefore act disculpatory in anticipation of liability. For that reason, the author argues that when assessing an appeal to disculpation, account must be taken of circumstances that necessitate the conclusion that a policymaker did not have the ability or means to intervene and take action to limit the damage.

Supervisory board members may also be held liable as (co-)policymakers (section 2:248 paragraph 1 jo. 7 DCC), while the law also provides for the liability of de facto supervisory board members (section 2:249 jo. 2:248 paragraph 1 jo. 7 DCC). The author discusses the scarce case law in which such examples have arisen and concludes that supervisory board members, despite the fact that they may have a very strong influence or considerable degree of control over the company's policy, will normally act within the limits of their legal authority, so that they only have to fear liability as a director in very exceptional cases.

The first part of this fourth chapter concludes with a discussion of sections 2:207 (repurchase of own shares), 2:208 (resolution to reduce capital) and 2:216 (dividend payment) DCC. The common denominator of these provisions is that the directors must give their approval when any kind of distribution is made to the shareholders. This approval must be refused if the directors know or should reasonably foresee that the company will not be able to continue to pay its due debts at a later date. The author first discusses the circumstance that these provisions relate to an internal liability (vis-à-vis the company), while the other provisions that provide for an assimilation of (co-)policymakers with formal directors relate to an external liability (vis-à-vis creditors). The author is critical of this mixture of internal and external liability. 


\subsubsection{False (co-)policymakers}

In the second part of this chapter, the author focuses his attention on the liability of (co-)policymakers on the basis of the general doctrine of tort (section 6:162 DCC). It starts with an explanation of the applicability of this provision to (co-)policymakers. Subsequently, the author considers whether this (co-)policymaker is the same as the one who can be held liable by virtue of an assimilation. He concludes that this is not the case and that the question of qualification in the application of section 6:162 DCC is not really necessary. The false policymaker distinguishes itself in the qualification question from the actual policymaker by the requirement typical of the latter, that he or she must have acted as if he or she were a director. In the light of section 6:162 DCC, the concept of the (co-)policymaker is erroneously assigned a functional meaning which leads to an unnecessary expansion of persons who can be held liable as a director on the grounds of a wrongful act. This is detrimental to the exceptional nature of the liability of this figure, as intended by the legislator.

This qualification issue is followed by a critical explanation of the standard used in assessing the liability of false (co-)policymakers. Currently, this standard is equal to the standard that is used when assessing the liability of directors towards creditors of the company on the grounds of section $6: 162$ DCC. This requires that serious blame can be attributed to the director personally. Because the common standard of section 6:162 DCC is exchanged for this special standard, a higher standard for liability applies to directors than outside cases of director's liability. The author argues that the justifications for accepting this higher threshold for liability do not apply to the (co-)policymaker. Consequently, this special standard cannot be applied in respect of the (co-)policymaker. Nevertheless, current case law shows that the liability of (co-)policymakers on the basis of section 6:162 DCC also requires that serious blame can be attributed to the (co-)policymaker personally.

Finally, the author discusses the application of section 2:11 DCC in the event of liability of (co-)policymakers pursuant to section 6:162 DCC. Since 2017, it has been established that the transfer of liability from legal entity-directors to their directors applies to all cases in which directors are held liable in their capacity. However, according to the author, there is no room to apply section 2:11 DCC when the liability of a (co-)policymaker is based on section 6:162 DCC. After all, both sections of the law lack a provision that provides for an equation of the (co-)policymaker with directors. 


\subsection{Piercing the corporate veil}

The fifth chapter deals with liability for the actual control of companies as a result of piercing the corporate veil. The first part deals with the doctrine of identification that is characterized as a direct form of piercing the veil. In such cases the principle that legal persons are equated with natural persons for property law purposes (section 2:5 DCC) is set aside. The second part of this chapter concerns an indirect form of piercing the veil, which leaves section 2:5 DCC intact but in fact achieves the same result. It is indirect, because the liability relates to obligations of the legal entity, but these are at the expense of the policymaker pursuant to section 6:162 DCC, because the policymaker personally committed a wrongful act against the creditor(s) of the legal entity. The author deals with this particular subject from the perspective of groups of companies, whereby a parent company is held liable for obligations of its subsidiary.

\subsubsection{Identification}

In cases of identification an exception is made to the principle of section 2:5 DCC by assimilating two or more (legal) persons. Thereby, one legal subject is equated with one or more other legal subjects and is considered as one (under property law). The author first characterizes the protection that directors derive from this provision and the limitation of shareholders' liability as a privilege, and concludes that this protection or limitation of liability can be regarded as a socially accepted phenomenon based on the joint benefit to society as a result of economic prosperity. Subsequently, it is established that legal personality and the limitation of liability preclude that those who act consciously, or who at least should reasonably have been aware of an damaging act, can be sued by the company's creditors, while the foreseeability of damage justifies looking beyond the company itself for liability. On the basis of the doctrine of identification, it can be determined when the aforementioned privilege must give way in favour of aggrieved creditors. Subsequently, the author discusses the case law in which the doctrine of identification has developed. It follows from this that the identification-cases and the abuse of legal personality in that regard are preferably tackled with the application of section 6:162 DCC, because in such cases the accusation to be made (frustrating of recourse) and the extent of the compensation obligation (assigning the underlying claim instead of compensating the damage as a result of frustrating recourse) often do not match up.

Although the author is of the opinion that the doctrine of identification should in principle be applied with restraint, he nevertheless advocates a wider applicability of this doctrine as a means to compensate creditor's damages. Finally, the author puts forward several viewpoints that could give more substance to the doctrine of identification. These are, on the one hand, 
derived from insights from case law and literature on misuse of power, sham actions and evasion of the law. On the other hand, the author refers to insights that can be derived from case law and literature on attributing actual acts and legal acts to legal persons, as well as the knowledge of officers of legal persons. It is concluded that the common denominator is always the perspective of the injured party and thus the extent to which the injured party has legitimately relied on the identity of its opposing party.

\subsubsection{The indirect form of piercing the corporate veil}

This doctrine has particularly developed in the case law on liability of parent companies. The author describes this development and observes that the (casuistic) case law on carelessness of parent companies is moving towards the acceptance of a duty of care on the part of the parent company towards creditors of its subsidiaries on the basis of the circumstances of the matter. In this respect, the factors (i) intensive involvement or control, (ii) insight into the subsidiary and (iii) the foreseeability of damages are particularly important.

After this description, the author provides a general explanation of duties of care under Dutch law in order to be able to approach the aforementioned criteria from this general framework. The liability for breach of a duty of care implies that there has been a failure to comply with that duty. In group relationships, the liability of a parent company for breach of its duty of care is essentially based on the accusation that it has failed to act where action in view of its insight into the subsidiary - was necessary and - in view of its control over the subsidiary - was possible. In the remainder of this paragraph, the author discusses the meaning of the duty of a parent company to exercise supervision over its subsidiaries ('group management duty') on the one hand and the intensive involvement of the parent company on the other hand in assessing its liability.

In short, the group management duty means that (the management of) a parent company is obliged to perform its duties properly towards the entire group. The author argues that as a parent company's involvement in its subsidiary increases, as a rule its insight into the subsidiary will also increase, so that it will have to be guided to a greater extent by the interests of the subsidiary in question. Only when the parent company expresses this involvement by interfering with its subsidiary on the basis of its (de facto) control, will it also have to bear a certain degree of responsibility. This is due to the fact that in that case the parent company must be deemed to be aware of the interests of its subsidiary's creditors and at the same time has the opportunity to respect those interests. However, it is in particular the requirement of intensive involvement or control that deserves attention in the assessment of liability. Such a degree of involvement leads to insight into and control over the subsidiary on the basis of which a duty of care on 
the part of the parent company can be present. At the same time, the degree of involvement determines whether and to what extent the parent company was able to intervene in the affairs of its subsidiary. The author advocates that if such a possibility to intervene is lacking, the parent company should not be liable to creditors of its subsidiary.

This chapter ends with a study into the possibilities of addressing a parent company as a (co-)policymaker within the meaning of section 2:248 paragraph 7 DCC. To this end, the author first raises the qualification question: when can a parent company be considered a (co-)policymaker of its subsidiary? The de facto (corporate) powers used to control subsidiaries and to (co-)determine their policies are relevant for answering this question. Neither the single fact that the parent company is a (majority) shareholder nor the existence of a group management duty is sufficient to addres the parent company as a (co-)policymaker pursuant to section 2:248 paragraph 7 DCC. The requirement that the parent company must have acted as if it were a director of its subsidiary implies that the parent company can only be regarded as a (co-)policymaker if it has stepped outside its role as 'central manager' of the group and the subsidiary's directors tolerate this or are set aside by the parent company. In addition, the parent company must have been managing the day-to-day affairs of the subsidiary directly by means of its de facto powers. Finally, the liability as (co-)policymaker is compared to the liability of parent companies on the basis of section 6:162 DCC (indirect form of piercing the veil). The author concludes that both forms of liability differ from each other, since in the case of (co-)policymaking it is particularly relevant in what way the parent company has interfered in the management of the subsidiary, whereas the indirect form of piercing the corporate veil requires a determination of the interference of the parent company with the policy of the subsidiary. After establishing this interference, an assessment must be made to what extent the parent company's insight into and (de facto) control over the subsidiary have been acquired as a result of such interference.

\subsection{The liability of limited partners}

The sixth chapter is the third and final part of the triptych on the actual control of companies. It focuses on the liability of the limited partner. Unlike the general partners of a limited partnership, the limited partner is not liable for the debts of the company and does not share in its losses above the amount of its contribution. Pursuant to section 20 of the Commercial Code (CC), the limited partner may not, among other things, get involved with the management of the company (the 'management prohibition'). In the event of a violation of this prohibition, the limited partner is jointly and severally liable for the company's debts on the basis of section $21 \mathrm{CC}$ and thus loses the privilege of limited liability. The author considers the background and scope of this management prohibition as well as the current 
criteria for assessing the liability of a limited partner. In addition, the author compares the liability of the limited partner with that of the (co)policymaker within the meaning of section 2:248 paragraph 7 DCC. At the end of this chapter, proposals for amendments to the current legislation on, among other things, the liability of limited partners are discussed.

The author argues that, in principle, the limited partner will have to be involved in matters that cannot be included in the day-to-day management of the company, so that the determination of the strategy of the limited partnership also falls within the competence of all partners jointly. Furthermore, the limited partner can indirectly influence the management of the limited partnership when certain decisions are subject to its approval or when the agreement of the partnership otherwise grants the authority to decide on internal matters. Finally, the limited partner is prohibited from representing the company. If the limited partner nevertheless acts in a representative capacity, this has two consequences: (i) the limited partner enters into the agreement with the other party instead of the company and (ii) the limited partner is jointly and severally liable for all obligations of the company.

\subsubsection{The management prohibition}

The management prohibition for limited partners is based on two principles. Firstly, it must be prevented that a limited partner abuses its privileged position resulting from limited liability by taking unacceptable risks when participating in legal transactions. Secondly, the management prohibition aims to prevent third parties from being misled by the limited partner. These third parties could easily mistake a limited partner for a general partner. Only the latter is jointly and severally liable for the obligations of the limited partnership. Keeping this background in mind, the author discusses the scope of the management prohibition. He observes that, currently, there are two main views on the scope of the management prohibition. The first, narrow interpretation of this scope limits the prohibited actions to purely external actions (i.e. towards third parties). Within the second, broader interpretation, the limited partner is completely forbidden to perform managerial acts, regardless of the involvement of third parties. In a more nuanced variant of this broad view it is assumed that internal acts of the limited partner are only prohibited in so far as these acts also have consequences for third parties. The author concludes that the limited partner is not entirely forbidden to be involved with the management of the company and in any case a certain degree of influence on the management is permitted internally. However, a dominant internal action of the limited partner must always lead to a violation of the management prohibition, insofar as this prohibition must (also) be considered as a provision aimed at preventing abuse and reckless actions under the protection of limited liability. 
Until 2015, a violation of the management prohibition for the limited partner had far-reaching consequences. This was the result of the characterisation of section $21 \mathrm{CC}$ as a penalty provision. According to the author, there was no reason to characterise the provision as such. However, it also offers the limited partner some protection, because a requirement of culpability is derived from this characterisation. The author concludes that liability also requires an active act on the part of the limited partner. Since 2015, liability of the limited partner pursuant to section $21 \mathrm{CC}$ is only justified if and to the extent that this liability is in accordance with the aforementioned background of the management prohibition. For this reason, its application may not be disproportionate to the nature and seriousness of the violation by the limited partner. Moreover, section $21 \mathrm{CC}$ cannot be applied if and insofar as the sanction is not, or not fully, justified by the actions of the limited partner. In addition, judges may deviate from the principle that a limited partner becomes liable for all obligations of the company. Finally, it may now also be of importance whether third parties were aware that they were dealing with a limited partner instead of a general partner. The author provides the relevant case law with general commentary in this respect and, within this framework, further clarifies the notions of 'disproportionality' and 'unjustified sanction'. With the framework for the liability of limited partners in mind, the author then considers whether the liability of limited partners is comparable to the liability of (co-)policymakers of legal persons. He does not consider this to be the case, because the relevant provisions differ too much from each other in design. This is despite the fact that both provisions partly share the same background and the fact that, since 2015, the assessment of the liability of limited partners shows similarities with the assessment of the liability of (co-)policymakers. There is, however, some convergence with regard to the nature of the relevant conduct: both the qualification as a (co-)policymaker and a violation of the management prohibition require an active action on the part of the (co-)policymaker and the limited partner respectively.

\subsubsection{Proposed amendments of statutory law}

In the last part of this chapter, the author discusses a private legislative initiative to reform the statutory law on partnerships proposed by the 'Werkgroep Personenvennootschappen' (Working Group), as well as the preliminary draft by the official legislator for new statutory law on partnerships, which is based on the aforementioned initiative of the Working Group.

In 2016, the Working Group presented a comprehensive proposal for new statutory law on partnerships. In this proposal, the limited partnership continued to exist as a separate legal form, including the limited liability of the limited partner. An important difference with the current provisions, however, is the proposal to allow limited partners to participate in the 
management of the limited partnership or even form the management, excluding general partners. In principle, however, the limited partner would not be allowed to represent the limited partnership. In addition, the Working Group's proposal included a complete revision of the limited partner's liability. In line with the above, it was proposed to abolish the management prohibition and furthermore to allow the limited partner to represent the limited partnership on the basis of a power of attorney. On the other hand, a new provision for liability, inspired by section 2:248 DCC, would be introduced to prevent misuse of these newly acquired powers. In the proposal the limited partner is jointly and severally liable for the deficit in case of bankruptcy of the limited partnership, if its actions by virtue of a power of attorney are an important cause of the bankruptcy. The author is critical of the proposed provision, because the wording of the proposed legal text cannot lead to the intended legal consequences. Moreover, the provision is limited to legal acts only. Damaging acts that are not considered to be legal acts cannot be dealt with by applying the proposed provision, nor does it make any link with liability resulting from, for example, mismanagement.

The legislator used the proposal by the Working Group as a basis for drawing up an official preliminary draft for new statutory law on partnerships. However, the legislator has chosen on the one hand to take provisions from the proposal of the Working Group and on the other hand to tinker with the text of these provisions, which does not improve the clarity of the official draft. Yet, the official preliminary draft does not affect the Working Party's proposal regarding the liability of limited partners acting by a power of attorney. The criticisms mentioned by the author on the proposal of the Working Group therefore apply equally to the official preliminary draft. In addition, the official preliminary draft is unclear about the extent to which limited partners can participate in the management of the limited partnership. 